\section{Kinga Majchrzak}

Uniwersytet Mikołaja Kopernika

\title{
Od miejsc pamięci narodowej do miejsc żywej pamięci - implikacje dla andragogiki
}

\author{
From national memorials to the places of living memory - \\ the implications for education
}

Streszczenie. Rozumienie miejsc pamięci w tym tekście wykracza poza wytwory kultury materialnej. Jego osnową są wartości transcendentalne, uniwersalne. Zaakcentowano w nim wielowymiarowość miejsc żywej pamięci, które dzięki swojej złożonej istocie mogą być zarówno obszarem edukacji formalnej, nieformalnej, jaki i pozaformalnej, edukacji skierowanej nie tylko do dzieci, ale także osób dorosłych. W artykule ukazano, że symboliczna natura miejsc żywej pamięci może stać się inspiracją do autorefleksji, impulsem do dalszych poszukiwań i samowychowania, które nabiera szczególnego znaczenia w postmodernistycznym świecie. Zaznaczono, że powodem rozwijania perspektywy edukacji opartej na miejscach pamięci jest skuteczne dostarczenie za jej pomocą wiedzy i doświadczenia potrzebnego do aktywnego uczestnictwa w procesie demokratycznym, możliwość wykorzystania jej na potrzeby edukacji obywatelskiej i ekologicznej. A zatem pedagogika miejsca cechuje się także społecznym ukierunkowaniem. Podkreślono, że cele i praktyka edukacji zorientowanej na miejsca żywej pamięci może być powiązana z uczeniem się eksperymentalnym, uczeniem problemowym, uczeniem się kontekstualnym, uczeniem się w działaniu, uczeniem się przez biografie miejsca, edukacją demokratyczną, edukacją multikulturalną, edukacją zorientowaną na wspólnotę lokalną oraz z inni nurtami dotyczącymi kontekstu i wartości uczenia się specyficznych miejsc, a także pielęgnowania ich, tak jak i wspólnot lokalnych czy regionów.

Słowa kluczowe: pomniki, miejsca pamięci, Pierre Nora, potencjał edukacyjny, edukacja.

Summary. Understanding places of remembrance in this text goes beyond the products of material culture. Its background are transcendental, universal values. Thanks to theirs complex nature places of remembrance can be both an area of formal, informal and nonformal education, education directed to all ages. Most of all, the symbolic nature of a places of remembrance can become an inspiration for auto-reflection, an impulse for further search and self-education, which assumes a special meaning in postmodern world. The reason for 


\section{2 | Kinga Majchrzak}

developing the perspective of education based on a places of remembrance is an effective way of supplying knowledge and experience necessary for active participation in the democratic process, the possibility to use it for the purpose of citizenship and ecological education. The objectives and practice of education oriented at a places of remembrance can be connected with experimental learning, problem learning, contextual learning, learning by doing, multicultural education, learning by the place biography, education oriented at the local community and other currents concerning context and the value of learning of specific places, as well as cultivating them as well as local communities or regions.

Keywords: memorials, place of remembrance, Pierre Nora, educational potential, education.

\section{Wprowadzenie}

Kulturę XXI wieku wyróżnia paradoksalność. Z jednej strony w niespotykanym dotąd stopniu nasycona jest produktami przeznaczonymi do szybkiej konsumpcji, a przy tym cechuje ją tymczasowość i relatywizm, które sprzyjają wykorzenieniu z miejsca i czasu (Melosik, 2001, s. 31-47; Musiał, 2011, s. 52). Z drugiej jest „czasem pamięci” (Nora, 2001, s. 37), w którym pamiętanie i upamiętnianie stało się wręcz modne (Traba, 2009, s. 66). Zdaniem Sławomira Kapralskiego (2010), żyjemy „w społeczeństwach w znacznej mierze ogarniętych amnezją, które jednakże rozwijają i pielęgnują rozmaite pasje i obsesje związane z pamięcią" (s. 20). Funkcjonujemy w kulturze posługującej się przede wszystkim „krótkim czasem”, czasem teraźniejszości, rozumianej jako seria następujących po sobie równie „ważnych-nieważnych" momentów, czego znakomitym przykładem są serwisy informacyjne (Szpociński, 2008, s. 18), a jednocześnie najbardziej zarchiwizowanej. Pierre Nora (2009) tłumacząc to zjawisko zauważa, że „(...) czujemy się zobowiązani do wytrwałego kolekcjonowania pozostałości, świadectw, dokumentów, obrazów, pogłosek, jakichkolwiek widzialnych znaków tego, co było, tak jakby to pęczniejące dossier miało być wykorzystane jako dowód przed nieznanym jeszcze trybunałem historii" (s. 7). Według tego badacza współczesnego człowieka ogarnęła potrzeba pamiętania, tyle tylko, że nie będąc w stanie wyselekcjonować co właściwie powinno zostać zapamiętane, odczuwa niechęć do pozbywania się różnych artefaktów przeszłości: „Imperatywem naszej epoki jest nie tylko zachowywanie wszystkiego, ocalenie każdej oznaki pamięci - nawet jeśli nie jesteśmy pewni, jakiego rodzaju pamięć oznaczamy - ale również tworzenie archiwów" (tamże, s. 7-8).

Prezentowaną prawidłowość odzwierciedla również obserwowane w ostatnich latach zainteresowanie miejscami pamięci wyrażające się po- 
pularnością badań dotyczących tej problematyki, szczególnie wśród przedstawicieli dyscyplin humanistycznych, zwłaszcza historyków i socjologów. Zdaniem Andrzeja Szpocińskiego (2008), wpływ na taki stan rzeczy mają zjawiska „wizualizacji” i „teatralizacji” kultury (s. 16). „Teatralizację" badacz utożsamia z wzrostem znaczenia, jakie w kulturze, a zwłaszcza kulturze historycznej, zaczynają odgrywać różnego rodzaju happeningi i działania performatywne, zaś przez pojęcie „wizualizacji” rozumie dominację wrażeń wzrokowych w procesach komunikacji społecznej (tamże, s. 17). Zjawiska te nierozerwalnie powiązane są z uhistorycznieniem przestrzeni. „Najogólniej rzecz ujmując, sens owej praktyki polega na ujawnianiu (i komunikowaniu) czasowego wymiaru rzeczywistości poprzez odpowiednie zagospodarowanie przestrzeni” (tamże, s. 18). Dzięki temu zabiegowi kawałki starych murów, bruki, nazwy ulic, tablice pamiątkowe, itp. stają się strażnikami pamięci i przez samą swą obecność, wywołując w obcujących z nimi jednostkami poczucie dawności, pobudzając do rozważań dotyczących ponadczasowości i przemijania. Niosą ze sobą emocje wynikające z „(...) poczucia więzi z tymi, którzy żyli tu kiedyś, którzy chodzili po tych samych brukach, dotykali tych samych klamek i drzwi, czytali te same napisy, z ludźmi, których dawno już nie ma i o których nic więcej nie wiemy. (...) Umożliwiają przeżywanie przeszłości, w której pierwszoplanową rolę odgrywa nie intelekt, lecz zmysły" (tamże, s. 18-19).

W tekście zwrócono uwagę na przesunięcie paradygmatyczne, które miało miejsce $\mathrm{w}$ badaniach historycznych $\mathrm{w}$ drugiej połowie XX wieku. Zaprezentowano skutki tego przesunięcie w zakresie teorii i eksplorowania miejsc pamięci. Odniesiono się do przeobrażeń, jakie niesie z sobą proces personalizacji i "de-terytoryzacji” miejsc pamięci na gruncie edukacyjnym, a przede wszystkim w praktycznym wymiarze edukacji dorosłych.

\section{(Re)definicje miejsc pamięci}

We współczesnej historiografii dokonała się zmiana paradygmatu, której istotą jest porzucenie XIX-wiecznej koncentracji na „państwie” i dominującego w XX w. zainteresowania „społeczeństwem”, na rzecz „pamięci” (Ankersmit, 2004, s. 367-371). Ale błędne byłoby stwierdzenie, że proces ten dotyczy tylko przedmiotu zainteresowań historiografii, której dzisiejsza różnorodność uniemożliwia tego typu uproszczenia. W istocie teza ta odnosi się do sposobu rozumienia nauk historycznych w ogóle, gdyż jej osnową są 


\section{4 | Kinga Majchrzak}

głębokie zmiany w teorii historii (Wóycicki, http://kazwoy.wordpress.com/ niemcy/zagadnienie-historiografii-pamieci/).

Owo paradygmatyczne przesunięcie zasadza się na skierowaniu zainteresowania historyków z obsesyjnego ustalania obiektywnych faktów na sposób, w jaki przeszłość jest/została zapamiętywana. Można wręcz stwierdzić, że wielu współczesnych historyków zajmuje się nie tyle samą przeszłością, co jej społecznym obrazem w świadomości poszczególnych podmiotów. Kategorią, która definiować i opisywać ma ów proces społecznego zapamiętywania jest właśnie „pamięć”, która w odróżnieniu od tradycyjnej wersji historii, jest wieloraka, polifoniczna, różnorodna, kontekstualna, nieustannie ewoluująca i choć mnoga/zbiorowa to jednocześnie indywidualna (Nora, 2001, s. 37; tenże, 2009, s. 5; Traba 2007, s. 20-21).

Nobilitacja pamięci umożliwiła odkrywanie fragmentów dziejów zepchniętych dotychczas na margines obowiązującego dyskursu. Dała szansę na zadośćuczynienie upokorzonym oraz deprecjonowanym jednostkom, czy grupom, poprzez umożliwienie im zaprezentowania własnej wersji zdarzeń, częstokroć odmiennej od tej, która funkcjonuje w wielkich narracjach upowszechnianych przez władzę, autorytety, a nawet uczonych. A także przyczyniła się do utraty przez historyków monopolu na interpretowanie przeszłości, ustalanie faktów, przytaczanie dowodów, wręcz objawianie prawdy, umacniane przez postrzeganie historii wyłącznie w kategoriach nauki. Współczesny historyk nie jest jedynym „producentem przeszłości”, dzieli tę rolę m.in. z sędziami, świadkami danych zdarzeń, prawodawcami, czy mediami (Nora, 2001, s. 41).

Nadejście w historii „czasu pamięci” odcisnęło również swoje piętno na teorii i praktyce związanej z miejscami pamięci. W tradycyjnym ujęciu miejsca pamięci postrzegane były (ale i są), jako „(..) grób lub cmentarz wojenny, nieruchomość lub obiekt budowlany albo jego posiadłości, upamiętniające postaci lub wydarzenia znaczące dla narodu i państwa, w szczególności pomniki, krzyż przydrożny, kapliczka, kopiec, tablica pamiątkowa" (Pinkiewicz-Gara, 2009, s. 154).

Zgodnie $\mathrm{z}$ tą definicją nadrzędnym celem istnienia zobiektywizowanych i „usakralizowanych” zarazem miejsc pamięci jest wspomaganie kształtowania świadomości narodowej obywateli danego państwa. Tak pojmowane miejsca pamięci mają wyłącznie materialną/przestrzenną postać, są pełne patosu i częstokroć posiadają martyrologiczną wymowę.

Paradygmatyczna zmiana, która zachodzi w naukach historycznych znacznie rozszerza zakres pojmowania miejsc pamięci. Współcześnie miejscami pamięci, wbrew topograficznej sugestii, określa się wszelkie niemal 
przejawy obecności przeszłości we współczesności (Kończal, 2007, s. 11). Prowadzi to do tego, że za metaforyczne miejsce pamięci - ważne nie tylko z punktu widzenia narodu, ale również innych, znacznie mniejszych grup społecznych - uznawać można nie tylko miejsca geograficzne czy architektoniczne, ale także realne i mityczne postaci, wydarzenia, pieśni, hasła, symbole, teksty literackie, święta, rytuały, zdjęcia, czy też tradycję, rozumianą zarówno w kategoriach regionu, grupy zawodowej, rodziny, jak i „(...) drobnych często niezauważalnych wydarzeń, które z czasem nabierają jakiegoś znaczenia(...)" (Unger, 2009, s. 197).

Za prekursora badań nad społecznymi, kulturowymi i politycznymi aspektami miejsc pamięci, wykraczającymi poza ich tradycyjne ujęcie i mieszczących się w kategorii żywej historii (bazującej na zindywidualizowanej i zdemokratyzowanej pamięci osadzonej w heterogeniczności mikroświatów społecznych), uznać należy Pierre’a Norę. Według tego francuskiego historyka miejsca pamięci są „(...) fundamentalnymi resztkami, najwyższymi wcieleniami pamięciowej świadomości, ledwie ocalałej w epoce historii, która przywołuje pamięć, gdyż ją porzuciła. Ukazują się dzięki derytualizacji naszego świata - tworząc, manifestując, ustanawiając, konstruując, dekretując i podtrzymując siłę postępu lub woli (...). Są jednocześnie proste i dwuznaczne, naturalne i sztuczne, bezpośrednio dostępne w konkretnym zmysłowym doświadczeniu i podatne na najbardziej abstrakcyjne przekształcenia" (Nora, 2009, s. 6).

Cytowany badacz, formułując zasadniczy cel istnienia/powoływania do życia miejsc pamięci, zwraca uwagę na ich znaczeniową wieloznaczność. Podkreśla, że funkcjonują one, aby: „zatrzymywać czas”, „zablokować proces zapominania”, „unieśmiertelnić coś martwego”, „zmaterializować coś niematerialnego", poprzez swoją metaforyczność. Bowiem miejsca pamięci są w stanie przekazać ogrom treści przy jednoczesnym wykorzystaniu minimalnej liczby znaków, dysponują zdolnością ewoluowania, permanentnego odradzania swoich znaczeń i niezliczoną ilością interpretacji (tamże, s. 10).

P. Nora dostrzega możliwość istnienia różnorodnych klasyfikacji miejsc pamięci. Dowodzi, że akcentując element funkcjonalny można by je podzielić na mające zachować „niekomunikowane doświadczenia”, np. związki weteranów i posiadające walor pedagogiczny, np. podręczniki, słowniki, testamenty itp. Zaś gdybyśmy skoncentrowali się na ich symbolice moglibyśmy na przykład przeciwstawić sobie dominujące i zdominowane miejsca pamięci. „Pierwsze z nich spektakularne i triumfalne, narzucające się i zazwyczaj narzucone - przez władzę narodową lub przez istniejące grupy interesu, ale zawsze odgórne - cechują się chłodem i powagą charakterystyczną dla ofi- 
cjalnych ceremonii. Raczej się je podziwia niż odwiedza. Drugim typem są miejsca schronienia, sanktuaria spontanicznej pobożności i milczącego pielgrzymowania, gdzie znajdujemy bijące serca pamięci" (tamże, s. 12).

Tego typu klasyfikacje można by mnożyć. Wydzielać miejsca pamięci publiczne i prywatne, wyczerpujące się w swej treści - jak mowa pogrzebowa, czy pole bitwy oraz złożone, w których element upamiętniający jest zaledwie jednym $\mathrm{z}$ wielu symbolicznych znaczeń, jak w przypadku flagi narodowej. Należy jednak pamiętać, że „wartością wstępnej próby klasyfikacji nie jest jej rygor czy zrozumiałość, ani nawet jej intelektualna moc lecz sam fakt, że jest możliwa. Już sama możliwość historii Lieux de meimoire dowodzi bowiem istnienia nici łączącej pozornie odległe od siebie przedmioty" (tamże, s. 12). Cechą wspólną miejsc pamięci jest pojmowanie ich, jako symboli utrwalonych w pamięci zbiorowej i kulturowej, jako spoiwa danej społeczności (Roszak, 2009, s. 7). Według P. Nory (2007), „pojęcie »miejsce pamięci« sugeruje poczucie przynależności, doświadczenie członkostwa we wspólnocie, wpisanie w czas, jak też okres wytwarzania, fermentacji. Sugeruje ramy, tradycję, tworzenie się zbiorowej wyobraźni oraz zespołu kolektywnych reprezentacji. Krótko mówiąc, sugeruje istnienie historii, którą naturalnie odczuwa się jako wspólną" (s. 7).

A. Szpociński (2009) zaznacza, że tak szeroki sposób rozumienia miejsc pamięci sprawia, iż atrybut ich materialności staje się kwestią drugorzędną: „Miejsca, o których jest tu mowa, mogą być rozumiane metaforycznie, jako jakiekolwiek znaki i symbole, które skupiają na sobie uwagę, ponieważ podejrzewa się, że są depozytariuszami przeszłości” (s. 15). Takie poszerzenie zakresu pojęcia miejsce pamięci jest uzasadnione, gdyż zarówno terytorialne jak i metaforyczne miejsca pamięci wyróżniają się specyficznymi cechami wspólnymi: są własnością określonych zbiorowości i zabezpieczają, takie lub inne, istotne z punktu widzenia danej grupy społecznej idee, normy, postawy, wzory zachowań, itp. Różnica pomiędzy nimi polega jedynie na tym, że w pierwszym wypadku „własność” pojmować można dosłownie, w drugim symbolicznie, gdyż w pierwszym oznacza „fizyczną” możliwość nawiedzenia określonych miejsc, a w drugim perspektywę powoływania się na nie jako na własną przeszłość (tamże, s. 15).

Można zatem stwierdzić, że posłużenie się przestrzenną metaforą miejsca w kontekście metaforycznych miejsce pamięci nie jest nadużyciem. Jak zapewnia A. Szpociński (2009) „imiona osób (na przykład margrabia Wielopolski), nazwy zdarzeń (na przykład wrzesień 1939) i wytwory kultury (na przykład Ostatnia wieczerza), niczym miejsca wykopalisk archeologicznych mogą stać się obszarem niekończących się poszukiwań, odkrywa- 
jących coraz to nowe, niedostrzegane lub niedoceniane wcześniej aspekty minionej epoki" (s. 15). Należy jednak pamiętać, że fundamentem każdego - zarówno fizycznego jak i metaforycznego miejsca pamięci - jest legitymowanie się dwiema podstawowymi własnościami: po pierwsze, dane wydarzenia, jednostki, wytwory kulturowe, muszą być interpretowane w potocznej świadomości, jako własność określonych grup lub zbiorowości, po drugie postrzegane jako skarbnica nie tylko jednej konkretnej wartości, lecz rzeczy ważnych uniwersalnie, „(...) ważnych dla wspólnoty, jako rodzaj »miejsca«, w którym znajdują się i mogą być odnajdywane coraz to inne cenne wartości" (tamże, s. 15). Przy takim sposobie rozumienia miejsca pamięci stają się jedną $\mathrm{z}$ form dochowania wierności przodkom i własnemu dziedzictwu oraz ocalenia znaczących dla następnych pokoleń, wartości, idei i wzorów zachowań.

\section{Od nauczania o miejscach pamięci narodowej do uczenia się miejsc żywej pamięci}

Zmiana paradygmatu w naukach historycznych, umożliwiająca generowanie spersonalizowanych zbiorów miejsc pamięci, podlegających permanentnemu procesowi tworzenia i zawierających zarówno przestrzenne (budowle, cmentarze, place itp.), jak i metaforyczne (postaci, daty, fotografie, piosenki, itp.) miejsca grupowych autodefinicji, koreluje z paradygmatycznym przesunięciem na gruncie pedagogiki, co ma swoje implikacje edukacyjne. Głównie dzięki osadzonym w Dewey'owskim progresywizmie przeobrażeniom w obszarze kształcenia umożliwia wyznaczanie nowych obszarów wykorzystania potencjału edukacyjnego miejsc pamięci, które wykraczają poza edukację historyczną (Majchrzak, 2012, s. 7-14) i stawia nowe wyzwania także przed andragogiką.

W celu opisu odmiennego podejścia do analizy miejsc pamięci wykorzystałam kategorie różnicujące zaproponowane przez Mieczysława Malewskiego w książce „Od nauczania do uczenia się. O paradygmatycznej zmianie w andragogice" (2010, s. 40).

Analiza tabeli 1 pozwala wnioskować, że tradycyjnie pojmowany proces edukacyjny oparty na miejscach pamięci podporządkowany jest dydaktyce technologicznej i służy konstruowaniu określonej tożsamości narodowej, zgodnej z interesami państwowości oraz będącej gwarantem jej trwania. Przekazywana w nim wiedza, przede wszystkim o charakterze faktograficznym, związana jest $z$ arbitralnie wyselekcjonowanymi przez zewnętrz- 
ne organy miejscami pamięci narodowej i uchodzić ma za obiektywną dzięki przesyceniu datami, nazwiskami i liczbami. Jej transmisja, rejestrowanie w umysłach uczących się, leży w gestii nauczyciela, który w tym celu posługuje się przede wszystkim metodami podającymi, np. wykładem. Miernikiem skuteczności podejmowanych przez niego wysiłków jest ilość informacji zapamiętanych przez uczące się osoby, których dotychczasowe doświadczenia, przemyślenia i odczucia są ignorowane w czasie działań edukacyjnych.

Tab. 1. Różnice podejścia do nauczania/uczenia się miejsc pamięci

\begin{tabular}{|c|c|c|}
\hline Kategorie różnicujące & Miejsca pamięci narodowej & Miejsca żywej pamięci \\
\hline $\begin{array}{l}\text { Najważniejszy problem } \\
\text { społeczny }\end{array}$ & Rozwój tożsamości narodowej & $\begin{array}{l}\text { Dochowanie wierności własnej prze- } \\
\text { szłości i przodkom }\end{array}$ \\
\hline Kluczowa wartość & Państwo & Pamięć \\
\hline Charakter wiedzy & $\begin{array}{l}\text { Zobiektywizowana (pochodząca } \\
\text { z wielkich narracji) }\end{array}$ & $\begin{array}{l}\text { Kontekstualna (biorąca pod uwage } \\
\text { zróżnicowanie społeczno-kulturowe) }\end{array}$ \\
\hline Rola nauczyciela & $\begin{array}{l}\text { Transmisja wiedzy (głównie fakto- } \\
\text { graficznej) }\end{array}$ & $\begin{array}{l}\text { Konstruowanie sytuacji edukacyjnej } \\
\text { sprzyjającej uczeniu się i poszukiwaniu } \\
\text { własnych interpretacji miejsc pamięci; } \\
\text { pobudzanie do samorozwoju }\end{array}$ \\
\hline Metody nauczania & Podające & Aktywizujące i bazujące na dialogu \\
\hline $\begin{array}{l}\text { Rola doświadczenia życiowe- } \\
\text { go stuchaczy }\end{array}$ & Bez znaczenia & $\begin{array}{l}\text { Jedno ze źródeł uczenia się; przesłan- } \\
\text { ka do autorefleksji }\end{array}$ \\
\hline
\end{tabular}

Źródło: Opracowanie własne na podstawie tabeli „Trzy dydaktyki dorosłych - podstawowe różnice” w: M. Malewski (2010) „Od nauczania do uczenia się. O paradygmatycznej zmianie w andragogice", Wrocław, s. 40.

Natomiast w działaniach pedagogicznych skoncentrowanych na miejscach żywej pamięci, kwestią drugorzędną jest reprodukcja określonych treści, gdyż pozyskiwana wiedza jest m.in. rezultatem interakcji zachodzących między uczestnikami procesu edukacyjnego. Istotą tego typu działań jest perspektywa zrozumienia, internalizacji, „przepracowania” konkretnych miejsc pamięci, które rozpatrywane są nie tylko pod kątem warstwy faktograficznej, ale przede wszystkim możliwości oddziaływania na sferę afektywną. Kwintesencją tego procesu edukacyjnego jest jego przebieg, możliwość uczestnictwa w nim, a tym samym definiowania lub redefiniowania własnej osoby, perspektywa wzbogacania tożsamości o nowe elementy, a rów- 
nież rozwijania umiejętności uczenia się. Nabywanie zdolności pamiętania, która nie prowadzi do zniewolenia, ale ubogaca poprzez zakorzenienie we własnej małej ojczyźnie, grupie zawodowej, rodzinie itp. O doborze miejsc żywej pamięci będących osnową działań edukacyjnych zmierzających do dochowania wierności własnej przeszłości decydują samodzielnie ich uczestnicy. W tak pojmowanym procesie edukacyjnym na nauczycielu, którym może być zarówno wykwalifikowany pedagog, jak i pracownik muzeum, czy działacz społeczny, spoczywa szereg zobowiązań. Za M. Malewskim powinien on być refleksyjnym organizatorem, jednostką gotową do nadawania rozwojowego i edukacyjnego charakteru elementom świata codziennego (tamże, s. 43), a równocześnie spełniającą funkcje: planistyczną, motywującą, metodyczną, udostępniającą, czy ewaluacyjną. Osobą opierającą swoje działania edukacyjne na dialogu z uczącymi się i zachęcającą ich do zgłaszania własnych pomysłów, czy autorefleksji. Wytworzeniu tego typu partnerskich relacji, a także uczeniu się siebie i od innych, sprzyja zastosowanie metod aktywizujących opartych na pracy zespołowej, jak np. organizacja gier miejskich i uczestnictwo w nich (Majchrzak, 2013, s. 133-148).

Należy jednakże pamiętać, że efektywność przejścia od „nauczania” do „uczenia się”, a nawet charakterystycznego dla dydaktyki krytycznej „poznania” miejsc żywej pamięci zwiększa szeroko rozumiana dojrzałość podmiotów edukacyjnych, gdyż w szerszej perspektywie oparty na nich proces edukacyjny przygotowywać ma uczących się do samodzielnego definiowania i interpretowania miejsc pamięci związanych m.in. z ich życiem rodzinnym, studenckim, czy zawodowym. Biorące w nim udział jednostki powinny legitymować się proedukacyjnymi postawami, charakterystycznymi dla uczenia się nieformalnego, którymi są: „1) proaktywność - uczący się sami określają kierunki poszukiwań najlepszego rozwiązania problemu i sprawują nad nimi pełną kontrolę; 2) refleksyjny krytycyzm - uczący się są krytyczni wobec uznanych wzorów rozwiązywania problemów danego typu oraz ukształtowanych na ich podstawie własnych przedsądzeń, przedrozumień i wartości; 3) kreatywność - uczący się są zdolni analizować problem z punktu widzenia innych uczestników sytuacji i odmiennych wartości" (Malewski, 2010, s. 59). Bardzo ważne jest także posiadanie przez jego uczestników szerokiego wachlarza doświadczeń życiowych. Również różnego rodzaju stereotypy, uprzedzenia, nieprawdziwe twierdzenia zbudowane na drodze obserwacji potocznej itp., mogą zaowocować pytaniami, być punktem wyjścia do dalszych poszukiwań, rozważań, czy dialogu (tamże, s. 29). 


\section{0 | Kinga Majchrzak}

\section{Podsumowanie}

Zaakcentowana wielowymiarowość miejsc pamięci i złożoność ich istoty sprawiają, że mogą one być zarówno impulsami/katalizatorami edukacji formalnej, pozaformalnej, jak i nieformalnej, edukacji skierowanej do wszystkich grup wiekowych. Dzięki symbolicznej naturze mogą stać się inspiracją do autorefleksji, impulsem do dalszych poszukiwań oraz samowychowania i samokształcenia, które nabiera szczególnego znaczenia w kontekście edukacji przez całe życie. Co ważne, cele i praktyka edukacji zorientowanej na miejsca pamięci może być powiązana z uczeniem się: eksperymentalnym, problemowym, przez biografię (miejsca), w działaniu, sytuacyjnym, kontekstualnym, edukacją: środowiskową i ekologiczną, demokratyczną, multikulturalną, regionalną i bio-regionalną (Grunewald, 2003).

\section{Bibliografia}

Ankersmit F. R. (2004), Narracja, reprezentacja, doświadczenie. Studia z teorii historiografii, Kraków.

Grunewald D. A. (2003), The Best of Both Worlds: A Critical Pedagogy of Place, "Educational Researcher", No. 4.

Kapralski S. (2010), Pamięć, przestrzeń, tożsamość [w:] Kapralski S. (red.), Pamięć, przestrzeń, tożsamość, Warszawa.

Kończal K. (2007), Polsko niemieckie-miejsca pamięci, „Borussia. Kultura. Historia. Literatura", $\mathrm{nr}$ 41(41).

Majchrzak K. (2013), Gra miejsca „Studenci UMK wobec miejsc (nie)pamięci”, „Dyskursy Młodych Andragogów", t. 14, Zielona Góra.

Majchrzak K. (2012), Places of Remembrance in Citizenship Education, "Journal of Education Culture and Society", No. 1.

Malewski M. (2010), Od nauczania do uczenia się. O paradygmatycznej zmianie w andragogice, Wrocław.

Melosik Z. (2001), Kultura instant - paradoksy pop-tożsamości [w:] Nalaskowski A., Rubacha K. (red.) Pedagogika u progu trzeciego tysiąclecia, Torun.

Hudzik P. J., Mizińska J. (red.) (1997), Pamięć. Miejsce. Obecność. Wspótczesna refleksja nad kultura $i$ ich implikacje pedagogiczne, Lublin.

Musiał Ł. (2011), O złej pamięci i dobrym zapominaniu, „Borussia. Kultura. Historia. Literatura", nr 49.

Nora P. (2001), Czas pamięci, „Res Publica Nowa”, nr 7.

Nora P. (2009), Między pamięciq i historiq̨: Les lieux de Memoire, „Tytuł Roboczy. Archiwum", nr 2. 
Nora P. (2007), W poszukiwaniu europejskich miejsc pamięci, „Borussia. Kultura. Historia. Literatura", nr 41.

Pinkiewicz-Gara B. (2009), Twierdza kłodzka - miejsce pamięci [w:] S. Roszak, M. Strzelecka, A. Wieczorek (red.), Miejsca pamięci w edukacji historycznej, Torun.

Roszak S. (2009), O miejscach pamięci [w:] Roszak S., M. Strzelecka, A. Wieczorek (red.), Miejsca pamięci w edukacji historycznej, Toruń.

Szpociński A. (2008), Miejsca pamięci (lieux de memoire), „Teksty Drugie”, nr 4.

Traba R. (2009), Historia wzajemnych oddziaływań (Beziehungsgeschichte) i konstrukcja „miejsc żywej pamięci” (lieux de memoire)? Przypadek Polski i Niemiec [w:] Noga Z., Wessel Schulze M. (red.), Pamięć Polska, pamięć Niemiecka od XIX do XX wieku. Wybrane problemy, Torun.

Traba R. (2007), Polifonia pamięci, „Borussia. Kultura. Historia. Literatura”, nr 41 s. 20-21.

Unger P. (2009), Tradycja też jest miejscem pamięci, [w:] Roszak S., Strzelecka M., Wieczorek A. (red.), Miejsca pamięci w edukacji historycznej, Torun.

\section{Netografia}

Wóycicki K., Zagadnienie historiografii pamięci, http://kazwoy.wordpress.com/ niemcy/zagadnienie-historiografii-pamieci/, (dostęp: 29.09.2013). 